This article was downloaded by: [University of Sydney]

On: 30 December 2014, At: 03: 30

Publisher: Routledge

Informa Ltd Registered in England and Wales Registered Number: 1072954

Registered office: Mortimer House, 37-41 Mortimer Street, London W1T

3J H, UK

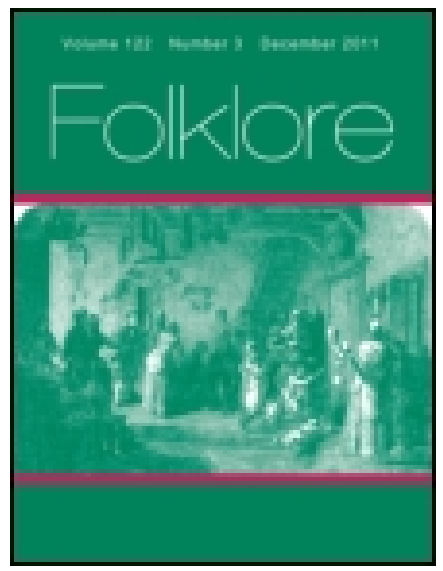

\title{
Folklore
}

Publication details, including instructions for authors and subscription information:

http:// www. tandfonline.com/loi/ rfol20

\section{Mystical and Ceremonial Avoidance of Contact with Inanimate Objects}

F. W. H. Migeod

Published online: 01 Feb 2012.

To cite this article: F. W. H. Migeod (1921) Mystical and Ceremonial

Avoidance of Contact with Inanimate Objects, Folklore, 32:4, 245-261, DOI: 10.1080/ 0015587X. 1921.9719208

To link to this article: http:// dx. doi.org/ 10.1080/0015587X.1921.9719208

\section{PLEASE SCROLL DOWN FOR ARTICLE}

Taylor \& Francis makes every effort to ensure the accuracy of all the information (the "Content") contained in the publications on our platform. However, Taylor \& Francis, our agents, and our licensors make no representations or warranties whatsoever as to the accuracy, completeness, or suitability for any purpose of the Content. Any opinions and views expressed in this publication are the opinions and views of the authors, and are not the views of or endorsed by Taylor \& Francis. The accuracy of the Content should not be relied upon and should be independently verified with primary sources of information. Taylor and Francis shall not be liable for any losses, actions, claims, proceedings, demands, costs, expenses, damages, and other liabilities whatsoever or howsoever caused arising directly or indirectly in connection with, in relation to or arising out of the use of the Content.

This article may be used for research, teaching, and private study purposes. Any substantial or systematic reproduction, redistribution, reselling, loan, sub-licensing, systematic supply, or distribution in any form to anyone is 
expressly forbidden. Terms $\&$ Conditions of access and use can be found at http://www.tandfonline.com/page/terms-and-conditions 


\section{MYSTICAL AND CEREMONIAL AVOIDANCE OT CONTACT WITH INANIMATE OBJECTS. ${ }^{1}$}

Read before the Anthropological Section of the British Association Edinburgh, Seplember, Ig21.

BY F. W. H. MIGEOD.

IN many primitive tribes there exists the idea that contact of the human body with an inanimate object, and especially with the ground, must be avoided on certain occasions for cither a ceremonial or a mystical reason. The thought secms to be that there is a loss of power or virtue should such contact take place. There must, therefore, be interposed some other material body, which in practice is usually something of special value; and the most valuable and efficacious of all is another human body. There are, it is true, other reasons than a loss of power or virtue to be assigned to such practices; but they are less common, and will be noted as they come up in the course of this paper.

A great many and very varied examples of avoidance of contact are to be found in Africa, where I have principally cnquired into this subject. They are not, however, confined to Africa alone. Many other semi-civilised or totally uncivilised countries furnish examples also. Among them arc Australia, in connection with the aboriginal inhabitants of course, the South Sea Islands, Borneo and India, and their comparison with each other is useful towards finding a clue to the underlying principle which is often the same

2 Attention may be drawn to the discussion of this question by Sir James Frazer (The Golden Bough, "Balder the Beautiful," vol. $i$. chap. 1.) with which the writer seems not to have been acquainted.-ED.] 


\section{Mystical and Cercmonial Avoidance}

in far distant countries. Whether there was anything similar among the aboriginal American tribes or nations I have been unable to ascertain.

The avoidance-of-contact idea is found in connection with the following pcrsons :

1. Boys on initiation to manhood.

2. Brides.

3. Persons initinted into secret societics.

4. Chicts.

5. Dancers.

6. Sacred inanimate objects.

No. 1. Initiation to Maniood.

In Australia the practice existed among the initiation rites of boys to manhood. (Frobenius, The Childhood of Man, quoting Collins.) 1 One of the ne:essary ceremonies was the removal of a tooth from the youth, which tonth was afterwards worn as an ornament. The ceremony of removal, which wins cffected by a sharp blow on a chisel, was performed whilst the youth was not in direct contact with the ground. One of the men of the tribe knclt down, and the youth sat on his shoulders holding on tightly while the percussion wins done, and until the tooth was at last broken off. Thereafter the patient added the name of his bearer to his own. This was witnessed in the carly days at Port Jackson, but in other parts of the continent it appears that the youth was simply laid on his back on the ground and the tooth knocked out, a much quicker and surce method.

Another cercinony was the introduction of the youths to the presumed chicfs of the initiation rites. Two men sat on tree stumps, each with another seated on his shoulders.

1 w. 1:. Roth, Elhnological Studies among the Noth-IVest-Centrat Queensland Aborigimes, t70: Sir 13. Spencer, Is. 1. Gillen, The Natice Tribes of Central Australia, 236. 
All the rest of the men lay on the ground, face downwards close together, and the boys walked on this living pavement to approach the seated figures.

Further, in other stages of the initiation the boys were carricl.

In British New Guinea (A. C. Haddon, "Migrations of Cultures in British New Guinea," in the Fournal of the Royal Anthropological Institute, 1920) among the initiation rites of boys to manhood we also find examples of non-contact with the ground. At one stage, the terminal feast of initiation among the Mawai, each boy stands on a dead pig, and whilst so standing is decorated emblematically. Again, after a probationary period of a month, the boy is steamed, and his mother tells him to stand on a dead pig, and he is invested with a loin cloth, and the initiation is completc. Among the Goi-cfu, on reaching puberty the boy, in the presence of the community, stands on a dead pig which his father has to provide, and whilst so standing is given moral and social instruction, as wcll as invested with a token of his manhood. New weapons are given him, and he is obliged to celebrate his initiation by killing a man or a wild pig afterwards. The same is found among the Binandele, in which tribe girls also stand on pigs; and similarly among other New Guinea tribes as well. This use of a pig, which at first sight scems a peculiar custom, is explaincd by the relationship of human flesh to pig flesh among the South Sea Islanders generally, the former being commonly called "long pig." There is also the legend of Dabadaba in support of this. It was he who persuaded the people to substitute pigs for men at sacrifices. The Goi-efu alternative of killing a man or a pig is further support for this theory. It is thus permissible to deduce, though there may be no surviving example of the practice, that in former times at initiation festivals the initiate stood on a human being. The old Australian aboriginal cercmonics witnessed by Collins seem to show that it was so. In other stages of the 


\section{Mystical and Coremonial Avoidance}

initiation ceremonies the boys are carricd to the "buck" or "medicine" house on the shoulders of their fathers and uncles. The full description in Haddon's article is as follows: "The persons carrying the boys wait outside the 'buck' till all the other men have entered. The men form a line across the hall and dance. Other men blow the flutes from behind the row of dancers. When the boys are brought into the hall, the pipers burst through the rows of dancers and press the flutes upon the navels of the boys. After further ceremonies the boys-are placed not on the bare ground but upon a picce of sago bark and taught to play the instruments. In a subsequent ceremony of going down to the river the boys are also carried by their fathers or uncles, and put into the water."

It is not unimportant to notice that those who carry the boys are their fathers or uncles, and to compare it with the Australian practice of the boy who has his tooth knocked out being carried by the man whose name he subsequently adds to his own, and, further, to compare it with the African example which is given below of the initiate into a sccret socicty walking on the body of the chicf of that society. In all cascs the sat-upon or walked. upon person is an clder or one in a higher position, and not an inferior.

\section{No. 2. TuE BRIDE.}

Coming now to marriage ceremonics it is not uncommon to find steps taken to guard the purity of the bride. In ancient times among the Romans it was the duty of the bridegroom to lift the bride over the threshold as she enterel her husband's house for the first time. In looking to sce if there was anything of this nature among African tribes I was told that among the Mende some, but I do not think all, the chiefs obscrve this custom by carrying the bride into the housc and laying her on the bed. Those that 
are not chiefs simply run more or less boisterously into the house without any ceremony. In any case I do not feel very sure about it as my informant was not a chief, and another man with whom I discussed it said there was no such ceremony. Nevertheless, it is probably observed at times, as among the Mandingo, to whom the Mende are related, the bride rides from her own house to that of the bridegroom on the shoulders of one of the bridegroom's fricnds.

In British New Guinea there is a similar custom. On Goaribari Island the bride is brought from her house to the bridegroom's father's house standing on a piece of bark supported on an oblong piece of heavy wood, which is carried by means of transverse sticks by her relations. The lower board is left there, and the bark board is taken by the bride's brother to the married men's house, and all the small boys go there and shoot arrows into it. (H. J. Ryan, quoted by Haddon.) In this it must not be overlooked that importance attaches to the object on which the girl stood.

There is an amplification of this custom in Africa. Among the Nkundo of the Juapa River, commonly called the High Nkundo in distinction with those lower down the river when it joins the Congo, when a big chief's daughter is going to be married she is shut up in a hut for two months before the ceremony. This probation is called "Luburu." A fire is kept burning in the hut. When she gocs outside for any purpose she must not walk on the ground. She must walk on "Mosolo," which is the name given to any article of value. So knives, anklets, bracelets, etc., I was informed, are laid on the ground, and on these she steps. Inside she is still supposed not to touch the ground, but sits with her fect resting on something. When the two months have expired she is carried through the town on a wooden bedstead by eight men, and dances all the time. The suitor then pays his headmoney and she is handed over. 
Among the Baganda, before marriage the bride was in the old days kept shut up for two wecks. If she went outside she put on sandals. On the marriage day the mecting with her husband took place halfway between the two houses. The bride was escorted on foot to this point. Here the bridegroom and his party met hers. On mecting, the bride was picked up by one of the husband's friends and carried on his shoulder to the husband's house. Here she was set down and crossed the threshold herself. After marriage she stayed indoors three wecks. In this it must be noted that, as with the Mandingo, it is not the bride. groom who carrics the bride but onc of his friends.

Great care used to be exercised by the Baganda lest a pregnant woman come in contact with another man. She used to be told the child would die, so as to frighten her. Slic must not shake hands with a man, nor should even his cloth touch lier in passing. So far was the non-intercourse idea cxtended, to say nothing of non-contact, that whilst a woman's husband was awny travelling she was not allowed to speak to another man unde". pain of something tcrrible happening. No doubt this last restriction was no more than one that had its origin in male jealousy.

Another case of which I have collected only one example may be mentioned here, although it is dissimilar. It is in relation to widows, and was observed by me in Ashanti. - It was in the town of Ejura. It was dusk, and the dancing after the funcral was finished for the time being. The widow, with her face whitened with clay was about to go home. Slie was not allowed to walk, but one of the young men present took her on his shoulders, and so she went to her house, a man on each side of her steadying her. I was told this was the widow, but there may have been a mistake, and she may have been a fetish.woman, who among other tribes are sometimes so carricd.

With brides perhaps the reason may be that she is regarded as a very precious object for which much in the 
way of goods has been paid. She must, therefore, be taken great care of, and accordingly is honoured in many ways, cven to the extent of being kept clear of contact with such a soiling thing as the ground. These ceremonies, therefore, have grown up and attach to her as an object of high value.

\section{No. 3. Initiation into Secret Societies.}

For initiation into secret societics, or into "medicine" as it may be called, there is a similar practice to that of initiating boys to manhood in Australia, though in this casc it is in Africa.

Among the Baluba (R. P. Collet on the Baluba) near the Lualaba River, as the Upper Congo is called, there is a socicty called the Bakangala. The initiate mects the head of the society lying in the path and covered with branches of trees, and must walk on his body. In another society initiation is completed by the head of the socicty lying on the initiate head to feet, the same practice being adopted if the initiate be a woman. Among the Baluba also the women of a certain society were treated with great respect. There were many special obscrvances with regard to them, among which was the one that they were not to walk about in public. If the fetish-woman went anywhere a special man attached to the socicty carried her on his shoulders, and, as in other tribes, he received special privileges. Among the Mende I am informed that a necessary accom. paniment of a certain initiation is bcing walked upon. In Bornco, among the Sea Dyaks, in the initiation to the third grade of Manang there is a waving over the initiate, followed in the fourth by the Manang desiring promotion being stamped upon. It can be seen in these examples quoted that whereas the action in all is not very dissimilar the reason is totally distinct. In the Mende and Sea Dyak practices the reason may possibly be to stamp out any evil spirit, and so scrve as an act of purification. The Baluba 


\section{2 Mystical and Corcmonial Avoidance}

practice on the other hand is akin to the Australian and New Guinea practice in boys' initiation of the superior person being in the lower position. The lying on the body of the initiate is quite apart, and possibly indicates a transference of powers by a different method.

\section{No. 4. Chiefs.}

The many customs and ceremonial observances attached to the office of chicf in Africa as well as clsewhere are cxcecdingly curious, and their meaning, to say nothing of their origin, is always not easy to explain in one way or another. It can only be by accumulating a grcat number of obscrved facts bearing on one particular practice and comparing them that any reasonable explanation can be arrived at, especially if immature or incomplete customs, if I may so call them, can be discovered.

In regard to the carrying of the chicfs, it may be put down generally to the desire to enhance their dignity. For instance, in the old day's among the Ashanti there was a regular scalc. The biggest chicfs had four men to carry their cradle, sccondary chicfs only two, while subordinate chicfs were entitled to one man only and rode on his shoulders. Among the Baganda the duty of carrying the king and royal family on their shoulders rested with one clan only. It was regarded as a privilege which was jealously guarded by them, and they would allow no one clse to do this.

When the South Sea Islands were first explored there were found to be in some of them chicfs who were regarded as sacred beings. They were held to be descended from the gods, and received much the same attention as if they were the gods themsclves. In Tahiti this was especially noticcable. Everything in connection with the king and queen were sacred-their cloths, houses, canoes and their bearcrs. Ground on which they accidentally trod, any 
housc they might enter became at once sacred and belonged to the king thenceforward, and in the case of the house the owner had to leave it never to return. Nobody might touch the king and queen, and anybody who stood over them or passed his hands above their heads was at once put to death. Great care had therefore to be exercised lest the royal pair should put their feet on any land not included in the royal domain, that is, in their own inherited district. When they went abroad they rode on the shoulders of certain attendants, who became sacred and were specially privileged men accordingly. If they were going far and one became tired, the king and queen passed on the neck of another man without descending, such a descent implying that the place would become sacred. In eating, too, on occasion the food had to be put into their mouths, by a sacred person, of course.

The carrying of chiefs by their attendants is common in various parts of Africa, but I do not gather that there is any underlying reason of sanctity in it. It seems to have its vogue from enhanced dignity and disinclination to walk. With the Tahiti chiefs the reason is quite different. It is because the chicfs are supposed to be descended from the gods, which may mean no more than that by origin they are descendants of some ancient conquering race, and may still posscss a minute strain of foreign blood. It is noticcable that carrying by their own followers is not met with in countries where there are horses or other animals. On the whole, except in regard to the South Seas, no special significance attaches to riding or bcing carried. It is a common custom throughout the world, as also is the accompanying assumption that the person who walks is in an inferior social position to one who rides.

Of a different nature, and one which may be ascribed in its origin to purcly intolerant arrogance, is the custom among some primitive chiefs ruling over a very subducd or slave population that one of them is the most suitable 


\section{Mystical and Cercmonial Avoidance}

object to furnish him with a seat. For instance, the chief of the Bushongo in southern Congoland would never sit on anything less important than one of his attendants or slaves. Another chicf seemed to have used his wives for this purpose. These were powerful and warlike chiefs, and chicfs of authority. Among the High Nkundo was the same practice, and the privilege pertained to the head chicf alone, except that on very special occasions apparently the head wife was also allowed a male slave to sit on. These privileges were undoubtedly intended to give some idea to all observers of the power and importance of the holders of the right, which certainly could not have been exercised without these attributes.

When the custom has died out perhaps its memory may be traced in the wooden seats carved in the shape of a man on all fours, such as have been found in some of the West India islands and supposed to be of Carib origin, an cxample of which is in the British Muscum, and similar ones of prescnt-day make which are made in the Northern Territorics of the Gold Coast.

Of somewhat different significance was the habit of a former big chief residing at Kasongo Nyembo in the head. waters region of the Congo, who made use of some of his wives to sleep on. Twelve of them werc laid out alternately: head and fect, and he lay on the top. No doubt this was only an example of an elderly man's search for a new sensation. Another custom of the same chicf has again a different significance, though what it is cannot be deduced with any degrec of certainty unless some similar practices can be reported. If the chicf dreamed of his ancestors he was not allowed to go outside the enclosure of his house all day; and if he cmerged from his hut his female slaves had to lie on the ground for him to walk on. We have seen that a betrothed girl among the Nkundo had to step on objects of value, because, possibly, before marriage she was an object of high valuc. Dreaming of his ancestors 
may clothe the chief temporarily with a special sanctity, and therefore he is only to be permitted to put his feet on objects of value also. It must not be overlooked that a fetish-priest may devise any sort of fanciful performance to meet any new case which may arise and be referred to him to advise on. There is no saying how many curious things may not have their origin in the past in the fertile brain of some old pricst.

In any case, walking on a living pavement is not confined to savage Africa nor to Australia. It is part of the ceremony of Doseh, which is or used to be performed in Egypt. ${ }^{2}$ It is only the chief of the two dervish orders of Saadites and Rifaites who has the right to pass on horscback along a human road. The dervishes lie down side by side, and the road is made perfectly straight. The horse is led by two men at its head, and the journey terminates at the house which is the sheikh's objective. As soon as the horse has passed the men who had lain down get up and are mixed up again in the crowd of sightscers.

Fortunately there is a history to this cercmony. Whether it is the true one is, of course, always an objection that can be raised.

The story is that a great saint and miracle-worker, once upon a time, came to Cairo and pitched his camp outside. The sultan went out to mect the saint, named Saad-ed.Din. Ile invited him to come into the town. After many refusals he at last agreed, but said he must perform a miracle so that all Mussulmans might listen to his word and repent of their sins forthwith. To do this he called upon all the inhabitants to bring all their valuable glass ware and spread it on his road, and when he made his entry into Cairo did it riding on the glasses, and legend has it without brcaking a single one. It is in commemoration of this miracle that the Doseh is performed, only at the present

IE. W. Lane, An Account of the Manners and Customs of the Modern Egyplians, sth ed. ii. 176 et segg. 


\section{Mystical and Ceremonial Avoidance}

day in licu of glasses and bottles human beings are substituted.

This ceremony, on account of there being $n$ historical reason assigned, is onc of very considerable importance when one endeavours to explain similar ceremonics in other lands, even though they may differ in some particulars.

There is a curious custom similar to the forcgoing among the Watusi in Ruanda, which is between lakes Tanganyika and Victoria, but with the addition of bloodshed. In addition to many human sacrifices being performed on the accession of a new king there used to be a very special one. A man, presumably of one of the subordinate tribes, was laid on the ground and covered with bark cloths. Then a herd of cattle was driven over him till he was pounded to death. The newly succeeding king had then to walk on the body its full length.

Perhaps if it were possible to observe all the surrounding rites on such a rarc occasion it might be possible to arrive at some explanation of this central rite. It may be cmblematic of the high position of the king with regard to his subjects, whom he can tread in the dust and at the same time kill with impunity. If, however, the sacrificed man is invariably a member of one of the subordinate tribes, as there is cvery reason to suppose, it may be emblematic and equally a warning to all subjects that the Watusi and their cattle are all equally superior to the subject agricultural nborigines whose country they invaded in remote times, and that the latter must regard the cattle as sacred.

It must not be overlooked that one of the prerogatives of kingship, at all events in Africa, is to have the power to take life at will and with no reason assigned. No king is a great king who has not the absolute power of life and death. Ile is not great if there are any limitations to his caprice. The treading on the corpse indicates this, and the means of doing it, namely employing cattle, further indientes the 
high position these animals occupy in the life history of a cattle-tribe.

Akin to the avoidance of contact with a harmful object by means of interposing a body is the interposing of something as a protection against hurtful rays from another person's eyes. In other words, to be seen performing certain actions may be hurtful, and something must be put between. This is found commonly in connection with drinking.

The old kings of Dahomey always had a cloth or several handkerchiefs held round their face if they drank anything at a time when anybody except their wives or other personal attendants were present. The same custom prevails among the far distant Baluba, and also, I think, among their neighbours the Basonge as well. Nobody is allowed to be present when the chief's water is drawn from the stream. Nobody must sce it carried up to the chief's house, so a boy goes on ahcad to clear the way; and the pot has to be covered with a cloth so that nobody may sce the water. As the custom of a chief not being seen drinking prevails also among the Banyoro, I belicve, it must be a very widespread one, and no doubt prevails among many intervening tribes.

$A$ last note on this subject I may make is that carly travellers selate that the King of Uganda was never allowed to touch any object, not cven a present, until it had been exorcised. Such a practice can only indicate that the king was possessed of a special sanctity, and accordingly had to be protected from any defilement.

In connection with the chiefly office, therefore, noncontact may be classified under three heads :

1. Sanctity of his person.

2. His dignity.

3. His arrogance. 


\section{No. 5. Dancers.}

With regard to dancers, avoidance of contact with the ground or other object is found among African tribes. Sccing that all primitive peoples are much given to dancing, hoth young and old and of both sexes, whenever any special safeguarding of the dancer is observed it must imply that there is spccial sanctity, or, if not sanctity, skill in that individual. Generally it is the former, as the dancing is connected with religious practices. Complete concealment of the body is found in some religious dances, and the dancer in such cases is usually a woman.

Among the Mende there is a female society of which the leading women are called Sowo-isia (the second part of the word being the plural termination). These women when dancing have no part of the body uncovered. The head is covered with a mask, and the fect are also fully bandaged, so that it is difficult to call the motions of the figure lancing, at least not graceful dancing. When the performance is over they retire to a hut to unrobe unsecn, so that in theory they remain unknown to the spectators. By this dress contact with any outside object is effectually guarded against. Other dancing girls in the same tribe when resting go straight to the line of lookers-on and sit on the knecs of some other woman, with their fect resting on the fect of the person beneath, so that no part touches the ground. If they touch thic ground it is thought that some of their skill, "Hale," medicine, in the wider application of the word, will leave them. I am not sure, however, that this practice is by any means of general application.

Thero secms nothing of this nature that applies to $\mathrm{men}$. dancers. It is true that after a dance a dancer who has danced well may be carried home by a friend on his shoulders, but it is simply a fancy procecding, something like "chairing" a winner in England, and there is no 
significance in it as regards the retention or loss of "medicine."

That the custom of lifting dancers off the ground is far spread may be seen from the custom of a tribe on the upper Mubangi River in Belgian Congo. (A. H. Savage Landor, Across Widest Africa.) Between the dances the girls are carried on the shoulders of the spectators or of specially appointed persons amongst them, usually standing upright. As there is no rest in such a position, such a motive cannot apply. It may therefore be so that they can be seen by everybody, and be done with the idca of honouring them.

Among the Nkundo on the Juapa River there is a dancing girl who is called a Kanga. She must not be touched or washed immediately before the dance, I gather, but palm oil and the red dye of the camwood tree are rubbed all over her. In some way she is sacred, and apparently a touch from an unauthorised person is held to be sure to spoil her dancing.

Though not an example of a similar nature I may mention a case of protection being accorded to a male dancer. In passing through the native part of the town of Lusambo on the Sankuru River (the inhabitants of which are largely Baluba, but many tribes are mixed therc) 1 met accidentally an important dancer in his dancing dress, which, especially the headdress, was of very superior manufacture. I wanted to photograph him, but in a moment a woman was interposed. Judging by the proximity of the woman when required, and by her taking her place without any hesitation, I am inclined to think that the procedure was a customary and frequent one so as to ward off any noxious influence. Incidentally I was much struck with this dancer in the few moments I saw him, he seemed of a very special type, although his face was absolutely expressionless.

On the whole it does not secm to be widely and gencrally 
understood that a dancer when not dancing needs to be specially guarded against direct contact with other material objects, unless their being completely covered indicates the necessity in itself and is not merely due to secrecy. In most tribes there is little or no ceremony. A dancer walks to the dancing place and returns without ceremony as a rule, for cverybody in the tribe at some time or other dances.

\section{No. 6. Sacred Inanimate Onjects.}

Sanctity when applied to inanimate objects necessitates their being guarded from pollution or hurt. The care bestowed on idols by idolatrous races is well known to all readers and observers. I will only mention here, therefore, two rather unusual cases.

In New Guinca there is the cult of the mango trec. A tree is selected and becomes at once sacred. It is cut down by fasting men with a special stone adze. Iron mus! not be used. All the chips, etc., are caught on new mats. The tree is wrapped in mats with all the chips and fallen leaves and carried to a certain place by the fasting men. There it is tied to the central pole of the platform inside the special house built for the fasting men. No part of the tree may ever touch the ground, and sacrifices of pigs are made to it. (A. C. Haddon, Migralion of Cullure.)

Finally, I may refer to the old Fiji custom of launching a new war canoc on the bodics of captured enemics instead of on wooden rollers. It may be with the idea of guarding the sanctity of the canoc, or perhaps the spirit of the canoc, against contamination. Or it may be no other than an additional and specially thought out fiendish device to render the launching sacrifice as attractive as possible to the jaded spirits of the spectators. Simple sacrifices usually accompanied a launch, and the idea is not lost in modern Europe, but. is represented by a bottle of wine being broken on the vessel's bows. 


\section{of Contact with Inanimate Objects. 261}

The common underlying principle in all these practices is, thereforc, for the most part in connection with sacredness, and as a safeguarding of the person concerned against the loss of that sacredness. In a few cases, as we have scen, it is to acquire a special virtue.

F. W. H. Mrgeod. 